\title{
Research on Strategies of International Trade under the Background of "One Belt and One Road”
}

\author{
Bo Liu \\ English School, China West Normal University, Nanchong, 637009, China
}

Keywords: One Belt and One Road, International trade, International logistics

\begin{abstract}
The "One Belt and One Road" initiative is conducive for Chinese further opening expansion and Chinese international trade process acceleration, which promotes China to be more fully into the tide of economic globalization. Under the background of "One Belt and One Road", the development of international trade shows the diversification trend of trade partners, balance trend of trade shape and convenient trend of trade logistics. Based on the above analysis, this paper gives the development strategies of China's international trade under the background of "One Belt and One Road” to provide some references for the relative researchers.
\end{abstract}

\section{Introduction}

In 2015, the formal implementation of "One Belt and One Road" strategy. "One Belt and One Road" strategy undoubtedly conforms to the trend of economic globalization, but also for the contemporary China planning future strategic planning. Under the background of economic globalization, international trade and capital flow are more frequent. However, for the sake of short-sighted interests, many countries have emerged as the main form of local protectionism, which is "trade barriers" and "capital barriers". In the short term, this kind of local protectionism can maintain the economic interests of the country to a certain extent, but in the long run, commodity trade and capital flow are beneficial to the economic development of the country. "The implementation of One Belt and One Road" strategy can not only promote the long-term benefits of economic growth, but also consider the short-term economic benefits. "The implementation of One Belt and One Road" strategy to promote economic upgrading along the more than fifty Asian and European countries in transition, to enhance the regional international trade activity, promote the economic development of the whole region. In Belt and Road Initiative policy in China and some neighboring countries formed a national collection of stakeholders, in this country in the aggregation between countries, political and cultural exchanges and economic exchanges greatly improved, not only promoted the development of China's economy, has established good cooperative relations with other countries, further laid China's international status. In the Belt and Road guidance, enhance the international trade amount greatly, and appears in the international trade friction, the friction will restrict the development of China's economy, the influence of international trade in china. Our country should move towards a road along with guidance on China's international trade re planning, to improve the effectiveness of international trade, to further promote the development of China's economy [2].

\section{Development Trends of International Trade under the Background of "One Belt and One Road”}

\subsection{Diversification trend of trade partners}

The formation of China's foreign trade situation in the diversification of trade partners and strategic conception of "One Belt and One Road" is closely related to implement. The diversification of our trading partners has encouraged our country to engage in trade with many other countries, and 
at the same time, it has greatly promoted export power and made the original export mode innovated. Then the structure of China's foreign trade is perfected. The economic development of the countries along the line is distinct, and the trade close to China is not the same. "There are significant differences in economic Belt and Road Initiative along the country's level of development and trade. The countries along the line include a small number of developed countries, as well as the least developed countries and many developing countries. This difference will make "One Belt and One Road construction is difficult to form a unified coordination mechanism, will also intensify multilateral negotiations difficult. Tariff barriers and non-tariff barriers are generally high, which bring challenges to trade liberalization and facilitation. "One Belt and One Road along the country mainly in developing countries, the least developed countries, the tariff barriers are at a high level, the trade between them constitute certain obstacles. In addition, due to the continuous expansion of China's trade surplus along the countries along the line, the industry has a certain homogeneous competition, which is easy to cause trade friction. The level of trade facilitation software is generally not high. Customs clearance efficiency, transparency of transit management and cumbersome customs clearance procedures impede trade liberalization. The rules system of international trade is still unstable. "Regional trade agreement One Belt and One Road" itself is not a close, still dominated Chinese along the country's trade in compliance with multilateral trade rules, bilateral trade agreement. In terms of bilateral free trade agreements, China has signed free trade agreements with only a few countries along the line. The rules of international trade between the two countries need further strengthening [3].

\subsection{Balance trend of trade shape}

One Belt and One Road world offers a huge market of trade facilitation, promote trade balance with the global economy. It conforms to the spirit of the supply side reform in our country and makes more quality goods oriented to the market. In addition, it will help to increase employment opportunities in our country. China is the world's largest exporter. Our Canton Fair and so on are all aimed at promoting trade exports, while China International Import Fair will increase our imports. In addition, China's economic development kinetic energy also promoted the demand for imported goods, which made China's trade surplus reduce, thus achieving a balance of international trade. It is beneficial to the promotion of China's scientific and technological level and the promotion and upgrading of China's industrial transformation. The most typical is the development of China's automobile industry. In recent years, with the opening of foreign car brands in China, the technology progress of domestic car brands has been continuously encouraged in the competitive environment, and the related technologies of domestic brands have been greatly improved. Most of the imported products in China have high quality and excellent technology, which promotes the iterative upgrading of our R \& D products in the market competition environment and helps to promote the progress of related industries. From the current pattern of China's foreign trade, trade development level of the western region is far lower than that of the eastern and central regions, especially with the eastern coastal areas of foreign trade compared to the level of it is far, so regional economic coordinative development and our country foreign trade development is intricately linked to. "One Belt and One Road" to the southwest and northwest regions of China's foreign trade. There is a new opportunity to promote the development of foreign trade in the western region of China, and then it can balance the domestic development of our country and reduce the regional gap greatly. Finally, promote the overall development of the economy [4].

\subsection{Convenient trend of trade logistics}

The essence of the development of international trade is to exchange and develop goods between the world by means of some international logistics technology, technology and equipment. In the process of mobility, we need to continuously promote the optimal allocation of market resources in the world and achieve good economic development in the world. With the continuous development of international trade, the demand for international logistics has been gradually improved. Logistics has become an important link of economic development between countries and countries. In the process 
of the development of international logistics trade, the logistics trade of goods is the basic component of the development of the world economy, and there is a close relationship between the two. This environment has also put forward a new development requirement for the operation of China's international trade and logistics enterprises. Under the support of China's policy of opening to the outside world, China's economic development has been gradually involved in the mainstream of world development, effectively improving China's international status. But It will gradually open the promise, it is a challenge to the development of some industries in china. A lot of international logistics enterprises to see the potential of our development in the international market, strengthen the investment in China, which are gradually enhance the overall status of China's international logistics enterprises, the whole industry is better in the development of the social economy to face the challenge and impact of international logistics industry. The implementation of the "One Belt and One Road" strategy is to alleviate the bottleneck of China's logistics development, has brought new opportunities for the development of logistics. We should get through the links between logistics enterprises and financial enterprises, take the development path of green and low carbon logistics, enhance the competitiveness of the logistics industry and better serve the rapid development of other related industries.

\section{Strategies of International Trade under the Background of "One Belt and One Road"}

\subsection{Strengthen trade initiative}

During international trade, enterprises are the main body of international trade project, want to improve the development of international trade, we first need to strengthen the initiative of China's trade, give full play to the initiative in the international trade market advantage, and obtain the corresponding trade advantage. Before trading, enterprises should communicate and communicate with the cooperative enterprises to improve the effectiveness of cooperation and exchange. At the same time, trade rules should be considered in the process of trade, and trade patterns should be determined according to trade rules, to ensure reasonable benefits and safeguard their legitimate rights and interests in the process of trade. In the process of trade, strengthening the initiative of trade can improve China's international status, to a certain extent, reduce the emergence of anti-dumping problems, and promote the development of our economy. To solve this problem by increasing demand: domestic infrastructure is one way to solve excess capacity; another way to expand demand is to expand overseas market. China traditional export the United States Europe and Japan are not suitable for the output of this infrastructure, "One Belt and One Road" neighboring countries is more conforming to this demand, through the "One Belt and One Road" to open new export market is a good starting point. "The development of One Belt and One Road" must rely on railway, highway, pipeline, shipping routes and gradually improve. Strengthening cooperation with more surrounding resources countries will also help to secure and enrich the access to resources. One Belt and One Road foreign strategy will contribute to the achievement of related countries and regions for mutual benefit and common development, the initiative of the surrounding trade and strengthening regional influence; help to improve the demand, promote a higher and more comprehensive development.

\subsection{Control dumping behaviors}

The implementation of "One Belt and One Road" strategy, the China will increase to countries along the large industrial exports and trade friction Chinese enterprises and developed countries industrial exports in the competition will inevitably produce. Chinese was faced with a variety of trade friction, therefore, "One Belt and One Road under China foreign trade friction situation will be intensified. Even if the implementation of the "One Belt and One Road" strategy is to achieve the full release of participation in the country's trade cooperation potential, but also cannot avoid the "cannot meet the Belt and Road along all countries and interests at the same time, lead to disagreements with other countries in. In addition, most of the countries along the line are labor-intensive products imported from China, and their prices are low. Therefore, the anti-dumping investigation of the 
importing countries will be very easy to happen. China enterprises and foreign developed countries, the trade friction between the implementation of the "One Belt and One Road" strategy will increase sharply. In the process of trade, we need to analyze the situation of trade and the industry of our country, to control the dumping behavior abroad, and our industry must cooperate effectively. Face in the market competition in the domestic market, the enterprises within the same industry for effective cooperation, solidarity, to establish the effective market mechanism, for the international trade market, the need to establish a mechanism of risk effectively, the dumping behavior may appear in the control and early warning, to prevent dumping phenomenon. In the process of international trade, we need to control the industry reasonably, make reasonable investigation and analysis of the existing import and export, and safeguard the legitimate rights and interests of our country through laws after we encounter the corresponding dumping behaviors of international trade. The control of dumping and the effective cooperation within the industry can promote the benign development of China's economic and trade.

\subsection{Cultivate innovative talents}

In the "One Belt and One Road" strategy, put forward higher requirements on the curriculum design, curriculum design of colleges and universities should be combined with the regional economic development. Depending on the local economic development features, some practical courses are set up. We should integrate the training mode with the international and serve the development of local characteristics. With the changing international situation, One Belt and One Road policy also makes the international trade situation has some changes, based on One Belt and One Road policy orientation, also need to integrate the international situation specific analysis, and thus to the planning of international trade. In the process of international trade, it is necessary to promote the transformation of China's trade, and the effective economic transformation can promote the benign development of our international trade. In addition to the international trade situation is changeable, should cultivate more innovative talents in trade, combine the current trade situation to make timely and effective treatment and analysis, to One Belt and One Road under the guidance, improve the development of China's international trade, to further promote the economic development of china. In the process of international trade, we also need to pay attention to the situation of rural labor force and make full use of rural labor force to make rational use of rural surplus labor force, which can not only promote our rural construction, but also provide vitality for China's economic development. If there are not enough teachers in international business, we can also consider hiring some business teachers who have experience in working with counterparts.

\section{Conclusion}

"One Belt and One Road" is planning to further accelerate the process of China's reform and opening, and further promote the international trade of the whole process of our country. By China powerful led to China, the absolute core of a more closely with neighboring countries, more in-depth international trade, by the integration of concurrence, concurrence and integration by the new economic era has carried out follow the prescribed order of international trade in China, the future development of the world is common aspiration.

\section{References}

[1] Shao Guang. Analysis of Collaboration between International Trade and International Logistics under "the Belt and Road Initiative": a Case Study of Guangdong Province [J]. Business Economy, 2016(6): 90-92.

[2] Wu Liqian, Xie Shuhua. International Trade of Agricultural Product under the Background of One Belt and One Road [J]. Journal of Anhui Agricultural Sciences, 2016, 44(2): 266-268.

[3] Li Jun, Cai Chunlin. A Review to the International Trade Effect of “the Belt and Road Initiative” 
and Prospects [J]. Reformation \& Strategy, 2016, 32(7): 150-154.

[4] Peng Yi, Zhao Huijun. The Expansion of Culture Spreading Function on College English Teaching in the Perspective of "One Belt and One Road Initiative" [J]. Forum On Contemporary Education, 2017(3): 83-91. 